\title{
DNA methylation in spermatogenesis and male infertility (Review)
}

\author{
XIANGRONG CUI ${ }^{1,2}$, XUAN JING $^{3}$, XUEQING WU $^{1}$, MEIQIN YAN $^{1}$, \\ QIANG $\mathrm{LI}^{1}$, YAN SHEN ${ }^{1}$ and ZHENQIANG WANG ${ }^{1}$ \\ ${ }^{1}$ Reproductive Medicine Center, Children's Hospital of Shanxi and Women Health Center of Shanxi, Taiyuan, \\ Shanxi 030000; ${ }^{2}$ Division of Clinical Microbiology The Center Hospital of Linfen, Linfen, Shanxi 041000; \\ ${ }^{3}$ Clinical Laboratory, Shanxi Province People's Hospital, Taiyuan, Shanxi 030001, P.R. China
}

Received February 6, 2015; Accepted April 6, 2016

DOI: $10.3892 /$ etm.2016.3569

\begin{abstract}
Infertility is a significant problem for human reproduction, with males and females equally affected. However, the molecular mechanisms underlying male infertility remain unclear. Spermatogenesis is a highly complex process involving mitotic cell division, meiosis cell division and spermiogenesis; during this period, unique and extensive chromatin and epigenetic modifications occur to bring about specific epigenetic profiles in spermatozoa. It has recently been suggested that the dysregulation of epigenetic modifications, in particular the methylation of sperm genomic DNA, may serve an important role in the development of numerous diseases. The present study is a comprehensive review on the topic of male infertility, aiming to elucidate the association between sperm genomic DNA methylation and poor semen quality in male infertility. In addition, the current status of the genetic and epigenetic determinants of spermatogenesis in humans is discussed.
\end{abstract}

\section{Contents}

1. Introduction

2. DNA methylation

3. DNA methylation and spermatogenesis

4. DNA methylation and genomic imprinting

5. DNA methylation and male infertility

6. Conclusion

Correspondence to: Professor Xueqing $\mathrm{Wu}$, Reproductive Medicine Center, Children's Hospital of Shanxi and Women Health Center of Shanxi, 13 Xinmin North Street, Taiyuan, Shanxi 030000, P.R. China

E-mail: cuixiangrong094030@163.com

Key words: DNA methylation, male infertility, spermatogenesis, epigenetics

\section{Introduction}

Epigenetics is the study of genomic structural modifications that affect gene expression without altering the underlying nucleotide sequence (1-3). Epigenetic mechanisms involved in the regulation of gene expression include the regulation of non-coding RNA, chromatin remodeling, DNA methylation and histone modifications $(4,5)$. Of these mechanisms, DNA methylation has been implicated in numerous biological functions, such as the development of spermatozoa and early embryos, and the repression of endogenous retrotransposons, while it also has a wide range of effects in gene expression $(2,3,6)$. The dysregulation of DNA methylation has previously been associated with various human disorders, and has been shown to increase the risk of fertilization failure, dysfunction in embryogenesis, perinatal mortality, congenital abnormalities, preterm birth and low birth weight (7-11). The present review assesses the significance of DNA methylation in spermatogenesis in order to elucidate the association between the dysregulation of DNA methylation and male infertility. This may provide a basis for the prevention and treatment of male infertility, as well as permit the evaluation of the epigenetic quality of sperm in order to reduce the risk of epigenetic diseases in cases where conception is performed by assisted reproductive technology (ART).

\section{DNA methylation}

Epigenetic mechanisms are critical regulators of gene expression during spermatogenesis that may influence male fertility (12-14). Cytosine, a key DNA base, is methylated at the position, typically in the context of $\mathrm{CpG}$ dinucleotides. The methylation of constitutive heterochromatic and promoter regions is generally associated with reduced gene transcription (Fig. 1A) (15-18). Therefore, DNA methylation is a type of epigenetic modification that can effectively promote gene silencing (Fig. 1B). The methyl group for this chemical modification of the DNA is donated by S-adenosyl-L-methionine (SAM) (17-22), and the methylation reaction is catalyzed by members of the DNA methyltransferases (DNMT) family, which are classified into the following three types in mammals: DNMT1, DNMT2 and DNMT3. It was demonstrated that DNMT1, DNMT3a and DNMT3b are robustly expressed in the early embryonic stage; however, the biological functions of DNMT2 remain elusive (23-25). 
A

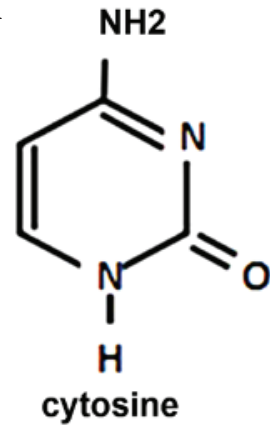

B

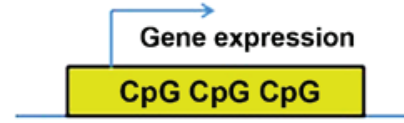

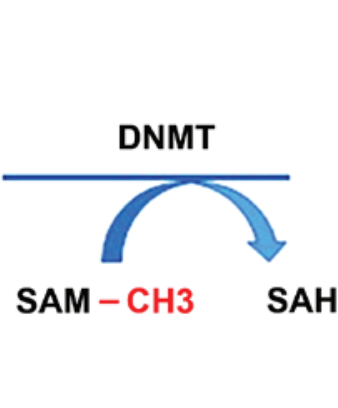

Figure 1. Characteristics of DNA methylation (Nasu,2011). (A) Cytosine is converted to 5'-methylcytosine by the action of DNMTs. (B) Cytosine is typically methylated in the context of $\mathrm{CpG}$ dinucleotides, and the methylation of constitutive heterochromatic and promoter regions is generally associated with gene silencing. SAM, S-adenosylmethionine; SAH, S-adenosylhomocysteine; DNMT, DNA methyltransferase.

DNMT1, which is the most abundant DNMT in mammalian cells (26-30), predominantly methylates hemimethylated $\mathrm{CpG}$ dinucleotides in the genome, and is considered to be the key maintenance methyltransferase during cell division (29-33). The DNMT2 gene is the most highly conserved of the methyltransferases in eukaryotes, and has been identified in organisms that exhibit DNA methylation, as well as in those that do not (26-30). DNMT3a and DNMT3b primarily perform de novo methyl transfer reactions via interactions with transcriptional repressors. They are considered to differ mechanistically due to inherent differences in their catalytic domains, and it has been suggested that DNMT3a is distributive while DNMT3b is processive (31-36). The third significant member in the DNMT3 family is DNMT3L, which is considered to be required for the establishment of maternal imprints in oocytes (37-41), and has also been shown to be expressed during spermatogenesis (37,42-44). SAM, as the methyl donor for DNMTs, is formed through the addition of adenosine triphosphate to methionine, which is catalyzed by the methionine adenosyltransferase enzyme. Subsequent to the methyl transfer reaction, SAM is converted into S-adenosyl-L-homocysteine, which acts as a potent inhibitor of DNMTs and histone methyltransferases (45-49).

\section{DNA methylation and spermatogenesis}

Germ cell development is a highly ordered process initiated during the growth of a fetus and is completed in adults. The epigenetic modifications occurring in germ cells are crucial for the function of germ cells and for embryonic development after fertilization $(50,51)$. Previous studies have demonstrated that male germ cells in adult mice have a highly distinct epigenetic pattern, characterized by a unique genome-wide pattern of DNA methylation (42,52-55). The methylation status of testicular DNA is highly distinct, displaying an eight times higher number of hypomethylated loci, as compared with somatic tissues $(51,56-58)$. Alterations in DNA methylation serve a crucial role in establishing an epigenetic state during the early stages in the development of germ cells, allowing for transcription to occur at the later stages (Fig. 2) (59-61).

Genome-wide methylation studies have demonstrated that the epigenomes of sperm cells and of somatic cells are significantly different; however, the sperm epigenome is very similar to that of embryonic stem cells (61-65). Using restriction landmark genomic scanning technology, DNA methylation was detected for chromosomes 6, 20 and 22 in spermatozoa, with numerous sites in sperm and somatic cells exhibiting varying degrees of methylation (66-68). The extent of methylation in sperm cells was significantly increased, as compared with fibroblasts $(>20 \%)$, liver cells $(10 \%)$, and $\mathrm{CD}^{+}$and $\mathrm{CD} 8^{+}$ lymphocytes $(5 \%)(68,69)$. DNA hypermethylation is associated with gene silencing. By contrast, hypomethylation is associated with gene expression. In sperm cells, promoters of developmental genes are highly hypomethylated. A previous gene ontology analysis demonstrated that hypomethylation in mature sperm cells promoted developmental transcription and signaling, which is bound by self-renewal mesh transcription factor of human embryonic stem cells, including OCT4, SOX2, NANOG, KLF4 and FOXD3 protein. Furthermore, recurrent regions of the sperm genome reportedly demonstrate high degrees of methylation, while transposons manifest weaker methylation. Whether other mechanisms exist requires further analysis $(65,69,70)$.

The paternally expressed human gene, MEST/PEG1, is demethylated in the fetus and remains unmethylated throughout all stages of sperm development in the adult life $(37,71)$. By contrast, in male germ cells, the $\mathrm{H} 19$ gene is methylated prior to meiosis at the spermatogonial stage of development $(37,72)$. Reinitiation of mitotic division of male germ cells during puberty coincides with an upregulation of DNMT1 within the spermatocytes. During the early stage of meiosis, DNMT1 levels in spermatocytes are increased; however, the level of the DNMT1 enzyme is reduced in pachytene stage spermatocytes $(37,73)$. In previous studies, the knockout of DNMT1 resulted in a lack of DNA methylation in the fetus, which, due to a lack of genomic imprinting, led to apoptosis 


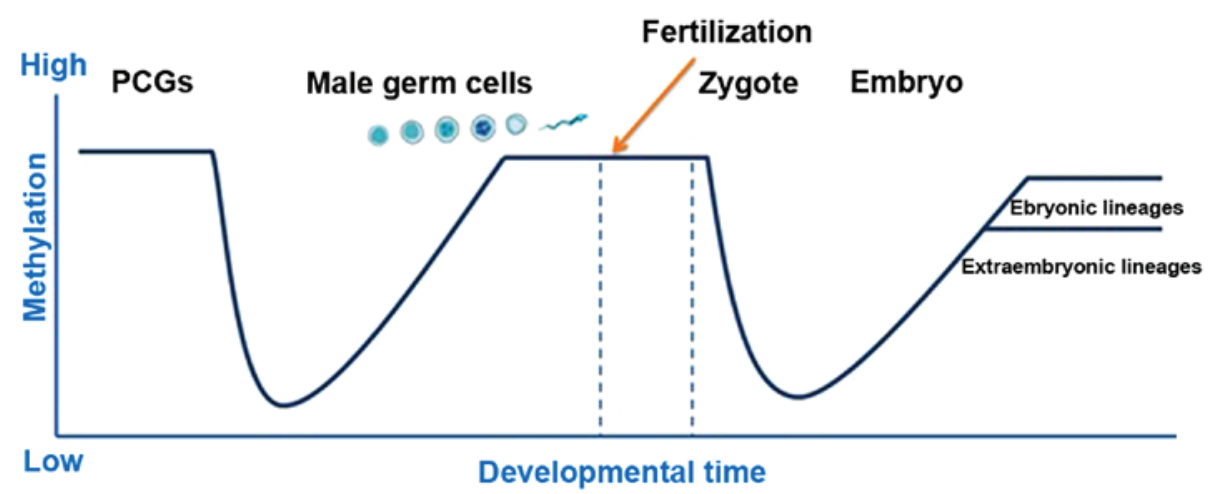

Figure 2. Methylation reprogramming in male germ cells (Dean, 2005). PGCs in mice become demethylated early in development. Re-methylation is initiated in pro-spermatogonia in male germ cells, and fertilization signals the second stage of methylation reprogramming. Thereafter, the paternal genome is demethylated by an active mechanism immediately following fertilization. PCGs, primordial germ cells.

of spermatagonial cells $(65,67,70,74)$. However, DNMT1 heterozygous mice had a normal reproductive ability, thus suggesting that DNMT1 in the heterozygous state is sufficient to maintain the required DNA methylation pattern $(30,75,76)$. DNMT3a expression in the testis is upregulated prior to birth and during early postnatal life, whereas DNMT3b expression is downregulated during embryonic development and upregulated postnatally (15-20). Notably, mice lacking DNMT3L have smaller testes, and a negligible number of spermatozoa by adulthood, resulting in sterile animals. In a previous study, DNMT3L was expressed only in germ cells, and the expression pattern was observed in males and females (77). However, in males, DNMT3L was initially detected at 12.5 days after fertilization of the egg, and the levels peaked at 15.5 days and remained upregulated until birth (77-79). However, the expression of DNMT3L was significantly 79 following birth and was found to be low in mature germ cells (36-38), suggesting an association between DNMT3L and DNA methylation. In addition, the inactivation of DNMT3L was shown to cause mitotic delays, chromosome synapsis errors and the ceasing of spermatogenesis at the zygotene stage of mitosis, thus inhibiting the maturation of germ cells (46-48).

In certain individuals with deletion mutations in DNMT genes, a proportion of the paternal differentially methylated regions (DMRs) were normal, which suggested that DNMTs have some functional duplication (77-79). Notably, oocytes lacking DNMT3L were able to undergo normal meiosis and exhibited methylation of repeat sequences; however, a significant lack of methylation-mediated imprinting existed only in the female imprinting positions (48-52). This difference in the effects of gene knockout between males and females raises the question of the divergent regulatory mechanisms between genders $(65,69)$.

\section{DNA methylation and genomic imprinting}

Genomic imprinting is an epigenetic mechanism resulting in parental expression of certain genes resulting in the alteration of gene transcription, while the actual gene sequence remains unchanged $(56,80,81)$. DNA methylation regulates genomic imprinting, thus resulting in only one inherited copy of the relevant imprinted gene being expressed in an embryo. The majority of imprinted genes contain DMRs, in which methylation differs between the paternal and maternal alleles. DNA methylation-mediated genomic imprinting is established during gametogenesis, prior to fertilization $(59,60)$.

By the time the primitive streak has formed during embryonic development [embryonic day 7.5 (E7.5)], the primordial germ cells (PGCs) carry the paternally and maternally inherited imprinting patterns (82). This DNA methylation pattern is maintained in PGCs, but is rapidly lost around E8, when PGCs begin to migrate towards the developing gonad. Upon their arrival at the genital ridge (between E10.5 and E11.5), global demethylation of mouse PGCs begins in order to remove their inherited imprinting pattern $(61,62)$. At this time, PGCs continue to proliferate and undergo differentiation into distinct male and female germlines (at $\sim$ E12.5), while the DNA methylation pattern of somatic cells is maintained. By E13-14, demethylation of the DNA is completed and male gametes are arrested at the prophase stage of mitosis $(59,60)$. It has previously been suggested that mitosis arrest may be required following demethylation, since the replication of unmethylated DNA has been associated with an increased risk of unrepressed retrotransposon transposition, which may lead to mutations. Therefore, in sperm cells, DNA methylation-mediated genomic imprinting is initiated prenatally, prior to meiosis, and is completed by the pachytene phase of postnatal spermatogenesis $(61,62,65,69,70,74)$.

\section{DNA methylation and male infertility}

Infertility is a major public health concern that has a significant social, psychological and economic impact, with an equal proportion of males and females affected (83-85). Male infertility is associated with genetic, environmental and numerous other factors $(86,87)$. The underlying mechanisms are unknown in $70 \%$ of male infertility cases, even in cases where the causes of male infertility are clear. Therefore, further studies are required in order to elucidate the mechanisms underlying male infertility. In male factor infertility, epigenetic modifications may serve a pivotal role by regulating male germ cell development and maintenance (88-92). Thus, abnormal imprinting as a result of DNA methylation dysregulation may be associated with male infertility.

Previous studies have demonstrated that disturbed spermatogenesis is associated with incorrect imprinting (74). 
An analysis of semen from infertile men has shown that $14.4 \%$ of anomalous patriarchal methylation occurred in H19 and gene trap locus 2 gene (93-95). In spermatozoa from oligozoospermic men, the occurrence of hypermethylation at several maternal DMRs or hypomethylation of H19 and intergenic-DMR was increased, particularly in patients with ejaculation volumes of $<10 \times 10^{6} / \mathrm{ml}(96-99)$. In men with oligoasthenoteratozoospermia, methylation was markedly reduced at all $\mathrm{CpGs}$, reaching statistical significance in subgroups with a sperm concentration of $<10 \times 10^{6} / \mathrm{ml}$. These findings suggest that abnormal DNA methylation-mediated genomic imprinting is associated with oligoasthenoteratozoospermia and oligozoospermia (100-107).

In patients with male infertility, paternally and maternally imprinted gene methylation abnormalities have previously been reported. In oligospermic patients, a low methylation or unmethylation pattern at the H19 imprinted gene has been associated with hypermethylation at the MEST imprinted gene, as well as a reduced sperm quality and decreased DNA methylation-mediated imprinting, as compared with fertile men $(108,109)$.

DNA methylation markers have been detected in the spermatogonia stage; therefore, the abnormal DNA methylation patterns observed in infertile men may be due to the failure of re-methylation in spermatogonia or alterations to methylation maintenance in spermatocytes, sperm cells or the mature sperm cell. In addition, abnormal DNA methylation may be associated with the abnormal activation of DNMTs (110-114).

Alterations in DNA methylation-mediated genomic imprinting have been observed more frequently in men with oligoasthenoteratozoospermia and oligozoospermia (115). However, whether methylation defects in imprinted genes will affect the development and growth processes of ART offspring remains to be elucidated. If epigenetic modifications are a key factor in the maturation of sperm cells, alterations in the epigenetic patterns of infertile men may provide a reasonable explanation for complications associated with ART, including low birth weight, premature births, congenital abnormalities, an increased perinatal mortality rate and pregnancy complications $(116,117)$. Embryos obtained from patients with hypospermatogenesis and almost complete hypomethylation at the H19 DMR following ART all exhibited developmental arrest $(117,118)$. However, patients with oligoasthenoteratozoospermia with a partial hypomethylation of $\mathrm{H} 19$ presented a reduced fertilization rate following intracytoplasmic sperm injection (ICSI). A previous analysis of the methylation status of ICSI infants with a low birth weight revealed hypermethylation at the MEST gene in one of the infants included in the study $(119,120)$.

\section{Conclusion}

In conclusion, DNA methylation has been closely associated with male infertility $(66,121)$. Understanding the mechanisms underlying DNA methylation is particularly important in order to develop therapeutic strategies for male genital system diseases caused by abnormal sperm DNA methylation. Studies on the mechanisms underlying the regulation of DNA methylation during spermatogenesis are still in their initial stages. Numerous issues remain, such as transgenerational inheritance of human epigenetic genes and the association between DNA methylation and other epigenetic factors, while it is unclear whether the risk of abnormal methylation-induced embryonic diseases has a threshold or is continuously increasing process.

\section{References}

1. Molaro A, Falciatori I, Hodges E, Aravin AA, Marran K, Rafii S, McCombie WR, Smith AD and Hannon GJ: Two waves of de novo methylation during mouse germ cell development. Genes Dev 28: 1544-1549, 2014.

2. Verma A, Rajput S, De S, Kumar R, Chakravarty AK and Datta TK: Genome-wide profiling of sperm DNA methylation in relation to buffalo (Bubalus bubalis) bull fertility. Theriogenology 82: 750-759 e751, 2014.

3. $\mathrm{Xu} \mathrm{C}$ and Song $\mathrm{N}$ : Epigenetic regulation in spermatogenesis. Zhong Hua Nan Ke Xue 20: 387-391, 2014 (In Chinese).

4. Dogra S, Sona C, Kumar A and Yadav PN: Epigenetic regulation of $\mathrm{G}$ protein coupled receptor signaling and its implications in psychiatric disorders. Int J Biochem Cell Biol 16: S1357-S2725, 2016.

5. Wang P, Zhang H, Hou H, Wang Q, Li Y, Huang Y, Xie L, Gao F, He S and Li L: Cell cycle arrest induced by inhibitors of epigenetic modifications in maize (Zea mays) seedling leaves: Characterization of the process and possible mechanisms involved. New Phytol: Apr 4, 2016 (Epub ahead of print).

6. Cheng P, Chen H, Zhang RP, Liu SR and Zhou-Cun A: Polymorphism in DNMT1 may modify the susceptibility to oligospermia. Reprod Biomed Online 28: 644-649, 2014.

7. Albertini DF: Relevant and irrelevant translational discovery and male infertility: The case of the Y chromosome and more! J Assist Reprod Genet 31: 1113-1114, 2014.

8. Chen J, Xiao HJ, Qi T, Chen DL, Long HM and Liu SH: Rare earths exposure and male infertility: The injury mechanism study of rare earths on male mice and human sperm. Environ Sci Pollut Res Int 22: 2076-2086, 2015.

9. Komiya A, Kato T, Kawauchi Y, Watanabe A and Fuse H: Clinical factors associated with sperm DNA fragmentation in male patients with infertility. ScientificWorldJournal 2014: 868303, 2014

10. Cheng BW, Guo H, Li ZF, Ma L, Wang YL, Yang LJ, Ye JJ and Zheng S: Identification of null and duplicated alleles for forensic DYS549, DYS527 and DYS459 in male infertility population. Yi Chuan 36: 786-792, 2014 (In Chinese).

11. Katib AA, Al-Hawsawi K, Motair W and Bawa AM: Secondary infertility and the aging male, overview. Cent European J Urol 67: 184-188, 2014.

12. Griseri P, Garrone O, Lo Sardo A, Monteverde M, Rusmini M, Tonissi F, Merlano M, Bruzzi P, Lo Nigro C and Ceccherini I: Genetic and epigenetic factors affect RET gene expression in breast cancer cell lines and influence survival in patients. Oncotarget: Mar 28, 2016 (Epub ahead of print).

13. DeVries A and Vercelli D: Epigenetic Mechanisms in Asthma. Ann Am Thorac Soc 13 (Suppl 1): S48-S50, 2016.

14. Kim SY, Morales CR, Gillette TG and Hill JA: Epigenetic regulation in heart failure. Curr Opin Cardiol 31: 255-265, 2016.

15. Jena SC, Kumar S, Rajput S, Roy B, Verma A, Kumaresan A, Mohanty TK, De S, Kumar R and Datta TK: Differential methylation status of IGF2-H19 locus does not affect the fertility of crossbred bulls but some of the CTCF binding sites could be potentially important. Mol Reprod Dev 81: 350-362, 2014.

16. Kuramochi-Miyagawa S, Kita-Kojima K, Shiromoto Y, Ito D, Koshima $\mathrm{H}$ and Nakano T: DNA methylation in mouse testes. Methods Mol Biol 1093: 97-109, 2014.

17. Schütte B, El Hajj N, Kuhtz J, Nanda I, Gromoll J, Hahn T, Dittrich M, Schorsch M, Müller T and Haaf T: Broad DNA methylation changes of spermatogenesis, inflammation and immune response-related genes in a subgroup of sperm samples for assisted reproduction. Andrology 1: 822-829, 2013.

18. Kläver R, Tüttelmann F, Bleiziffer A, Haaf T, Kliesch S and Gromoll J: DNA methylation in spermatozoa as a prospective marker in andrology. Andrology 1: 731-740, 2013.

19. Calicchio R, Doridot L, Miralles F, Méhats C and Vaiman D: DNA methylation, an epigenetic mode of gene expression regulation in reproductive science. Curr Pharm Des 20: 1726-1750, 2014. 
20. Gan H, Wen L, Liao S, Lin X, Ma T, Liu J, Song CX, Wang M, $\mathrm{He} \mathrm{C}$, Han C, et al: Dynamics of 5-hydroxymethylcytosine during mouse spermatogenesis. Nat Commun 4: 1995, 2013.

21. Boissonnas CC, Jouannet P and Jammes H: Epigenetic disorders and male subfertility. Fertil Steril 99: 624-631, 2013.

22. Mychasiuk R, Harker A, Ilnytskyy S and Gibb R: Paternal stress prior to conception alters DNA methylation and behaviour of developing rat offspring. Neuroscience 241: 100-105, 2013.

23. Paluch BE, Naqash AR, Brumberger Z, Nemeth MJ and Griffiths EA: Epigenetics: A primer for clinicians. Blood Rev: Feb 26, 2016 (Epub ahead of print).

24. Liu X, Zhou P, Lu Y and Luo Y: Progresses of DNA methylation in common ocular tumor. Zhonghua Yan Ke Za Zhi 51: 950-954, 2015 (In Chinese)

25. Wijenayake S and Storey KB: The role of DNA methylation during anoxia tolerance in a freshwater turtle (Trachemys scripta elegans). J Comp Physiol B 186: 333-342, 2016.

26. Ko YG, Yun J, Park HJ, Tanaka S, Shiota K and Cho JH: Dynamic methylation pattern of the methyltransferase1o (Dnmt1o) 5 '-flanking region during mouse oogenesis and spermatogenesis. Mol Reprod Dev 80: 212-222, 2013.

27. Okamura E, Matsuzaki H, Sakaguchi R, Takahashi T, Fukamizu A and Tanimoto K: The H19 imprinting control region mediates preimplantation imprinted methylation of nearby sequences in yeast artificial chromosome transgenic mice. Mol Cell Biol 33: 858-871, 2013

28. Meikar O, Da Ros M and Kotaja N: Epigenetic regulation of male germ cell differentiation. Subcell Biochem 61: 119-138, 2013.

29. Bose R, Adiga SK, D'Souza F, Salian SR, Uppangala S, Kalthur G, Jain N, Radhakrishnan RA, Bhat N, Krishnamurthy $\mathrm{H}$, et al: Germ cell abnormalities in streptozotocin induced diabetic mice do not correlate with blood glucose level. J Assist Reprod Genet 29: 1405-1413, 2012.

30. Saferali A, Moussette S, Chan D, Trassler J, Chen T, Rozen R and Nauvoma AK: DNA methyltransferase 1 (Dnmt1) mutation affects Snrpn imprinting in the mouse male germ line. Genome 55: 673-682, 2012

31. Kato Y and Nozaki M: Distinct DNA methylation dynamics of spermatogenic cell-specific intronless genes is associated with CpG content. PLoS One 7: e43658, 2012.

32. Zhang GL, Zhang XF, Feng YM, Li L, Huynh E, Sun XF, Sun ZY and Shen W: Exposure to bisphenol A results in a decline in mouse spermatogenesis. Reprod Fertil Dev 25: 847-859, 2013

33. Coral S, Covre A, Nicolay HJ, Parisi G, Rizzo A, Colizzi F, Dalla Santa S, Fonsatti E, Fratta E, Sigalotti L, et al: Epigenetic remodelling of gene expression profiles of neoplastic and normal tissues: Immunotherapeutic implications. Br J Cancer 107: $1116-1124,2012$

34. Jenkins TG and Carrell DT: The sperm epigenome and potential implications for the developing embryo. Reproduction 143: 727-734, 2012

35. Carrell DT: Epigenetics of the male gamete. Fertil Steril 97 $267-274,2012$

36. van Montfoort AP, Hanssen LL, de Sutter P, Viville S, Geraedts JP and de Boer P: Assisted reproduction treatment and epigenetic inheritance. Hum Reprod Update 18: 171-197, 2012.

37. Marques CJ, Joao Pinho M, Carvalho F, Bieche I, Barros A and Sousa M: DNA methylation imprinting marks and DNA methyltransferase expression in human spermatogenic cell stages. Epigenetics 6: 1354-1361, 2011.

38. Niles KM, Chan D, La Salle S, Oakes CC and Trasler JM: Critical period of nonpromoter DNA methylation acquisition during prenatal male germ cell development. PLoS One 6: e24156, 2011.

39. Rajender S, Avery K and Agarwal A: Epigenetics, spermatogenesis and male infertility. Mutat Res 727: 62-71, 2011.

40. Le Bouc Y, Rossignol S, Azzi S, Brioude F, Cabrol S, Gicquel C and Netchine I: Epigenetics, genomic imprinting and developmental disorders. Bull Acad Natl Med 194: 287-297, 2010 (In French).

41. Navarro-Costa P, Nogueira P, Carvalho M, Leal F, Cordeiro I, Calhaz-Jorge C, Gonçalves J and Plancha CE: Incorrect DNA methylation of the DAZL promoter $\mathrm{CpG}$ island associates with defective human sperm. Hum Reprod 25: 2647-2654, 2010.

42. Takashima S, Takehashi M, Lee J, Chuma S, Okano M, Hata K, Suetake I, Nakatsuji N, Miyoshi H, Tajima S, et al: Abnormal DNA methyltransferase expression in mouse germline stem cells results in spermatogenic defects. Biol Reprod 81: 155-164, 2009.

43. Yaman R and Grandjean V: Timing of entry of meiosis depends on a mark generated by DNA methyltransferase $3 \mathrm{a}$ in testis. Mol Reprod Dev 73: 390-397, 2006.
44. Tucker KL, Beard C, Dausmann J, Jackson-Grusby L, Laird PW, Lei H, Li E and Jaenisch R: Germ-line passage is required for establishment of methylation and expression patterns of imprinted but not of nonimprinted genes. Genes Dev 10: 1008-1020, 1996

45. Gebert C, Kunkel D, Grinberg A and Pfeifer K: H19 imprinting control region methylation requires an imprinted environment only in the male germ line. Mol Cell Biol 30: 1108-1115, 2010.

46. Colosimo A, Di Rocco G, Curini V, Russo V, Capacchietti G, Berardinelli P, Mattioli M and Barboni B: Characterization of the methylation status of five imprinted genes in sheep gametes. Anim Genet 40: 900-908, 2009.

47. Boissonnas CC, Abdalaoui HE, Haelewyn V, Fauque P, Dupont JM, Gut I, Vaiman D, Jouannet P, Tost J and Jammes H: Specific epigenetic alterations of IGF2-H19 locus in spermatozoa from infertile men. Eur J Hum Genet 18: 73-80, 2010.

48. Trasler JM: Epigenetics in spermatogenesis. Mol Cell Endocrinol 306: 33-36, 2009.

49. Feil R: Epigenetic asymmetry in the zygote and mammalian development. Int J Dev Biol 53: 191-201, 2009.

50. Schoenmakers S, Wassenaar E, Hoogerbrugge JW, Laven JS, Grootegoed JA and Baarends WM: Female meiotic sex chromosome inactivation in chicken. PLoS Genet 5: e1000466, 2009.

51. Marques CJ, Francisco T, Sousa S, Carvalho F, Barros A and Sousa M: Methylation defects of imprinted genes in human testicular spermatozoa. Fertil Steril 94: 585-594, 2010.

52. Godmann M, Lambrot R and Kimmins S: The dynamic epigenetic program in male germ cells: Its role in spermatogenesis, testis cancer, and its response to the environment. Microse Res Tech 72: 603-619, 2009

53. Henckel A and Feil R: Differential epigenetic marking on imprinted genes and consequences in human diseases. Med Sci (Paris) 24: 747-752, 2008 (In French).

54. Houshdaran S, Cortessis VK, Siegmund K, Yang A, Laird PW and Sokol RZ: Widespread epigenetic abnormalities suggest a broad DNA methylation erasure defect in abnormal human sperm. PLoS One 2: e1289, 2007.

55. Tanaka H: Regulation of gene expression in spermatogenesis Tanpakushitsu Kakusan Koso 52 (Suppl 1): 2116-2123, 2007 (In Japanese).

56. Rijlaarsdam MA, Tax DM, Gillis AJ, Dorssers LC, Koestler DC, de Ridder J and Looijenga LH: Genome wide DNA methylation profiles provide clues to the origin and pathogenesis of germ cell tumors. PLoS One 10: e0122146, 2015.

57. Minor A, Chow V and Ma S: Aberrant DNA methylation at imprinted genes in testicular sperm retrieved from men with obstructive azoospermia and undergoing vasectomy reversal. Reproduction 141: 749-757, 2011.

58. Peltomäki P: DNA methylation changes in human testicular cancer. Biochim Biophys Acta 1096: 187-196, 1991.

59. Kato Y, Kaneda M, Hata K, Kumaki K, Hisano M, Kohara Y, Okano M, Li E, Nozaki M and Sasaki H: Role of the Dnmt3 family in de novo methylation of imprinted and repetitive sequences during male germ cell development in the mouse. Hum Mol Genet 16: 2272-2280, 2007.

60. Oakes CC, La Salle S, Smiraglia DJ, Robaire B and Trasler JM: Developmental acquisition of genome-wide DNA methylation occurs prior to meiosis in male germ cells. Dev Biol 307: 368-379, 2007

61. Delaval K, Govin J, Cerqueira F, Rousseaux S, Khochbin S and Feil R: Differential histone modifications mark mouse imprinting control regions during spermatogenesis. EMBO J 26: 720-729, 2007.

62. Paoloni-Giacobino A, D'Aiuto L, Cirio MC, Reinhart B and Chaillet JR: Conserved features of imprinted differentially methylated domains. Gene 399: 33-45, 2007.

63. Chong S, Vickaryous N, Ashe A, Zamudio N, Youngson N, Hemley S, Stopka T, Skoultchi A, Matthews J, Scott HS, et al: Modifiers of epigenetic reprogramming show paternal effects in the mouse. Nat Genet 39: 614-622, 2007.

64. Paoloni-Giacobino A: Epigenetics in reproductive medicine. Pediatr Res 61: 51R-57R, 2007

65. Omisanjo OA, Biermann K, Hartmann S, Heukamp LC, Sonnack V, Hild A, Brehm R, Bergmann M, Weidner W and Steger K: DNMT1 and HDAC1 gene expression in impaired spermatogenesis and testicular cancer. Histochem Cell Biol 127: 175-181, 2007.

66. Gunes S, Arslan MA, Hekim GN and Asci R: The role of epigenetics in idiopathic male infertility. J Assist Reprod Genet: Mar 3, 2016 (Epub ahead of print). 
67. Laurentino SS, Borgmann J and Gromoll J: On the origin of sperm epigenetic heterogeneity. Reproduction REP-15-0436, 2016.

68. Casas E and Vavouri T: Sperm epigenomics: Challenges and opportunities. Front Genet 5: 330, 2014

69. Rousseaux S, Faure AK, Thévenon J, Escoffier E, Lestrat C, Govin J, Hennebicq S, Sèle B, Caron C and Khochbin S: Epigenetics of the sperm cell. Gynecol Obstet Fertil 34: 831-835, 2006 (In French).

70. La Salle S and Trasler JM: Dynamic expression of DNMT3a and DNMT3b isoforms during male germ cell development in the mouse. Dev Biol 296: 71-82, 2006.

71. Riesewijk AM, Hu L, Schulz U, Tariverdian G, Höglund P, Kere J, Ropers HH and Kalscheuer VM: Monoallelic expression of human PEG1/MEST is paralleled by parent-specific methylation in fetuses. Genomics 42: 236-244, 1997.

72. Kerjean A, Dupont JM, Vasseur C, Le Tessier D, Cuisset L, Pàldi $\mathrm{A}$, Jouannet $\mathrm{P}$ and Jeanpierre $\mathrm{M}$ : Establishment of the paternal methylation imprint of the human H19 and MEST/PEG1 genes during spermatogenesis. Hum Mol Genet 9: 2183-2187, 2000.

73. Li Z, Dai H, Martos SN, Xu B, Gao Y, Li T, Zhu G, Schones DE and Wang Z: Distinct roles of DNMT1-dependent and DNMT1-independent methylation patterns in the genome of mouse embryonic stem cells. Genome Biol 16: 115, 2015.

74. Hartmann S, Bergmann M, Bohle RM, Weidner W and Steger K: Genetic imprinting during impaired spermatogenesis. Mol Hum Reprod 12: 407-411, 2006.

75. Roberts AR, Blewitt ME, Youngson NA, Whitelaw E and Chong S: Reduced dosage of the modifiers of epigenetic reprogramming Dnmt1, Dnmt3L, SmcHD1 and Foxo3a has no detectable effect on mouse telomere length in vivo. Chromosoma 120: 377-385, 2011.

76. Ray D, Wu A, Wilkinson JE, Murphy HS, Lu Q, Kluve-Beckerman B, Liepnieks JJ, Benson M, Yung R and Richardson B: Aging in heterozygous Dnmt1-deficient mice: Effects on survival, the DNA methylation genes, and the development of amyloidosis. J Gerontol A Biol Sci Med Sci 61: 115-124, 2006.

77. Matsuoka T, Kawai K, Ando S, Sugita S, Kandori S, Kojima T, Miyazaki J and Nishiyama H: DNA methyltransferase-3 like protein expression in various histological types of testicular germ cell tumor. Jpn J Clin Oncol hyw012, 2016.

78. Vlachogiannis G, Niederhuth CE, Tuna S, Stathopoulou A, ViiriK, de Rooij DG, Jenner RG, Schmitz RJ and Ooi SK: The Dnmt3L ADD Domain Controls Cytosine Methylation Establishment during Spermatogenesis. Cell Rep 15: S2211-S1247, 2015.

79. Liao HF, Chen WS, Chen YH, Kao TH, Tseng YT, Lee CY, Chiu YC, Lee PL, Lin QJ, Ching YH, et al: DNMT3L promotes quiescence in postnatal spermatogonial progenitor cells. Development 141: 2402-2413, 2014.

80. Yiran Z, Meiling Z, Zhichao Z, Yunjiao Z and Xin M: Epigenetic regulation of genomic imprinting in germline cells and preimplantation embryos. Yi Chuan 38: 103-108, 2016 (In Chinese).

81. von Meyenn F and Reik W: Forget the Parents: Epigenetic Reprogramming in Human Germ Cells. Cell 161: 1248-1251, 2015.

82. Chaillet JR, Vogt TF, Beier DR and Leder P: Parental-specific methylation of an imprinted transgene is established during gametogenesis and progressively changes during embryogenesis. Cell 66: 77-83, 1991

83. Hajder M, Hajder E and Husic A: The Effects of Total Motile Sperm Count on Spontaneous Pregnancy Rate and Pregnancy After IUI Treatment in Couples with Male Factor and Unexplained Infertility. Medical archives 70: 39-43, 2016.

84. Mintziori G, Kita M, Duntas L and Goulis DG: Consequences of hyperthyroidism in male and female fertility: Pathophysiology and current management. J Endocrinol Invest: Mar 8, 2016.

85. Dupree JM, Dickey RM and Lipshultz LI: Inequity between male and female coverage in state infertility laws. Fertil Steril: Mar 5, 2016 (Epub ahead of print).

86. Bolduc S, Fischer MA, Deceuninck G and Thabet M: Factors predicting overall success: A review of 747 microsurgical vasovasostomies. Can Urol Assoc J 1: 388-394, 2007.

87. Liang J, Zhang Y, Yu Y, Sun W, Jing J and Liu R: Effect of chromosomal polymorphisms of different genders on fertilization rate of fresh IVF-ICSI embryo transfer cycles. Reprod Biomed Online 29: 436-444, 2014.

88. Oldereid NB, Hanevik HI, Bakkevig I, Romundstad LB, Magnus $\varnothing$, Hazekamp J, Hentemann M, Eikeland SN, Skrede S, Reitan IR, et al: Pregnancy outcome according to male diagnosis after ICSI with non-ejaculated sperm compared with ejaculated sperm controls. Reprod Biomed Online 29: 417-423, 2014.
89. Wosnitzer M, Goldstein M and Hardy MP: Review of Azoospermia. Spermatogenesis 4: e28218, 2014.

90. Guerrero-Bosagna C and Skinner MK: Environmentally induced epigenetic transgenerational inheritance of male infertility. Curr Opin Genet Dev 26: 79-88, 2014.

91.Komiya A, Kawauchi Y, Kato T, Watanabe A, Tanii I and Fuse $\mathrm{H}$ : Sperm nuclear vacuoles in relation to acrosome reactions and sperm motility. ScientificWorldJournal 2014: 178970 , 2014.

92. Xu AM, Liu BJ and Wang ZJ: DAZL and male infertility: an update. Zhonghua Nan Ke Xue 20: 647-650, 2014 (In Chinese).

93. Khazaie Y and Nasr Esfahani MH: MicroRNA and Male Infertility: A Potential for Diagnosis. Int J Fertil Steril 8: 113-118, 2014

94. Barazani Y, Agarwal A and Sabanegh ES Jr: Functional sperm testing and the role of proteomics in the evaluation of male infertility. Urology 84: 255-261, 2014.

95. Komori K, Tsujimura A, Okamoto Y, Matsuoka Y, Takao T, Miyagawa $\mathrm{Y}$, Takada S, Nonomura $\mathrm{N}$ and Okuyama $\mathrm{A}$ : Relationship between substances in seminal plasma and Acrobeads Test results. Fertil Steril 91: 179-184, 2009.

96. Dada R, Kumar M, Jesudasan R, Fernández JL, Gosálvez J and Agarwal A: Epigenetics and its role in male infertility. J Assist Reprod Genet 29: 213-223, 2012.

97. Bhattacharyya T, Gregorova S, Mihola O, Anger M, Sebestova J, Denny P, Simecek P and Forejt J: Mechanistic basis of infertility of mouse intersubspecific hybrids. Proc Natl Acad Sci USA 110: E468-E477, 2013

98. Pacheco SE, Houseman EA, Christensen BC, Marsit CJ, Kelsey KT, Sigman M and Boekelheide K: Integrative DNA methylation and gene expression analyses identify DNA packaging and epigenetic regulatory genes associated with low motility sperm. PLoS One 6: e20280, 2011.

99. Soubry A, Hoyo C, Jirtle RL and Murphy SK: A paternal environmental legacy: Evidence for epigenetic inheritance through the male germ line. BioEssays 36: 359-371, 2014.

100. Owen CM and Segars JH Jr: Imprinting disorders and assisted reproductive technology. Semin Reprod Med 27: 417-428, 2009

101.Childs AJ, Saunders PT and Anderson RA: Modelling germ cell development in vitro. Mol Hum Reprod 14: 501-511, 2008.

102. Cortessis VK, Thomas DC, Levine AJ, Breton CV, Mack TM, Siegmund KD, Haile RW and Laird PW: Environmental epigenetics: Prospects for studying epigenetic mediation of exposure-response relationships. Hum Genet 131: 1565-1589, 2012.

103. Berthaut I, Montjean D, Dessolle L, Morcel K, Deluen F, Poirot C, Bashamboo A, McElreavey K and Ravel C: Effect of temozolomide on male gametes: An epigenetic risk to the offspring? J Assist Reprod Genet 30: 827-833, 2013.

104. Crews D: Epigenetics and its implications for behavioral neuroendocrinology. Front Neuroendocrinol 29: 344-357, 2008.

105. Gabory A, Attig L and Junien C: Epigenetic mechanisms involved in developmental nutritional programming. World J Diabetes 2: 164-175, 2011.

106. Katari S, Turan N, Bibikova M, Erinle O, Chalian R, Foster M, Gaughan JP, Coutifaris C and Sapienza C: DNA methylation and gene expression differences in children conceived in vitro or in vivo. Hum Mol Genet 18: 3769-3778, 2009.

107. Feuer SK, Camarano L and Rinaudo PF: ART and health: Clinical outcomes and insights on molecular mechanisms from rodent studies. Mol Hum Reprod 19: 189-204, 2013.

108.Zama AM and Uzumcu M: Epigenetic effects of endocrine-disrupting chemicals on female reproduction: An ovarian perspective. Front Neuroendocrinol 31: 420-439, 2010.

109. Niemitz EL and Feinberg AP: Epigenetics and assisted reproductive technology: A call for investigation. Am J Hum Genet 74: 599-609, 2004

110. Lee J and Shinohara T: Epigenetic modifications and self-renewal regulation of mouse germline stem cells. Cell Res 21: 1164-1171, 2011.

111. Li L, Le F, Wang LY, Xu XR, Lou HY, Zheng YM, Sheng JZ, Huang HF and Jin F: Normal epigenetic inheritance in mice conceived by in vitro fertilization and embryo transfer. J Zhejiang Univ Sci B 12: 796-804, 2011.

112. Wasson JA, Ruppersburg CC and Katz DJ: Restoring totipotency through epigenetic reprogramming. Brief Funct Genomics 12: $118-128,2013$. 
113. Daxinger L and Whitelaw E: Transgenerational epigenetic inheritance: More questions than answers. Genome Res 20 $1623-1628,2010$.

114. Skinner MK: Environmental epigenomics and disease susceptibility. EMBO Rep 12: 620-622, 2011

115. Kitamura A, Miyauchi N, Hamada H, Hiura H, Chiba H, Okae H, Sato A, John RM and Arima T: Epigenetic alterations in sperm associated with male infertility. Congenit Anom (Kyoto) 55: 133-144, 2015

116. Marques CJ, Costa P, Vaz B, Carvalho F, Fernandes S, Barros A and Sousa M: Abnormal methylation of imprinted genes in human sperm is associated with oligozoospermia. Mol Hum Reprod 14: 67-74, 2008.

117. Montjean D, Ravel C, Benkhalifa M, Cohen-Bacrie P, Berthaut I, Bashamboo A and McElreavey K: Methylation changes in mature sperm deoxyribonucleic acid from oligozoospermic men: Assessment of genetic variants and assisted reproductive technology outcome. Fertil Steril 100: 1241-1247, 2013.
118. Kobayashi H, Hiura H, John RM, Sato A, Otsu E, Kobayashi N, Suzuki R, Suzuki F, Hayashi C, Utsunomiya T, et al: DNA methylation errors at imprinted loci after assisted conception originate in the parental sperm. Eur J Hum Genet 17: 1582-1591, 2009.

119. Pliushch G, Schneider E, Schneider T, El Hajj N, Rösner S, Strowski T and Haaf T: In vitro maturation of oocytes is not associated with altered deoxyribonucleic acid methylation patterns in children from in vitro fertilization or intracytoplasmic sperm injection. Fertil Steril 103: 720-727, 2015.

120.Zheng HY, Shi XY, Wang LL, Wu YQ, Chen SL and Zhang L: Study of DNA methylation patterns of imprinted genes in children born after assisted reproductive technologies reveals no imprinting errors: A pilot study. Exp Ther Med 2: 751-755, 2011

121. Xu J, Zhang A, Zhang Z, Wang P, Qian Y, He L, Shi H, Xing $Q$ and Du J: DNA methylation levels of imprinted and nonimprinted genes DMRs associated with defective human spermatozoa. Andrologia: Jan 25, 2016 (Epub ahead of print). 